\title{
Internal Damping Depending on the Deformation Amplitude Measured on Magnesium Alloys
}

Milan Uhríčik ${ }^{1}$, Zuzana Dresslerová ${ }^{1}$, Peter Palček ${ }^{1}$, Monika Oravcováa ${ }^{1}, Z_{\text {Zuzanka Trojanová2 }}$

${ }^{1}$ Department of Materials Engineering, Faculty of Mechanical Engineering, University of Žilina, Univerzitná 8215/1, 010 26 Žilina, Slovakia. E-mail: milan.uhricik@fstroj.uniza.sk, zuzana.dresslerova@fstroj.uniza.sk, peter.palcek@fstroj.uniza.sk, monika.oravcova@fstroj.uniza.sk

${ }^{2}$ Department of Physics of Materials, Faculty of Mathematics and Physics, Charles University in Prague, Ke Karlovu 5, 12116 Praha 2, Czech Republic. Email: ztrojan@met.mff.cuni.cz

The article is aimed on the analysis of the internal damping changes depending on the amplitude of the magnesium alloys AZ31 and AZ91 in as cast state. In experimental measurements was used only resonance method, which is based on continuous excitation of oscillations of the specimen and the entire apparatus vibrates at a frequency which is near to the resonance. Starting resonance frequency for all measurements was about $f=20470 \mathrm{~Hz}$. These mechanisms have been studied by ultrasonic resonant apparatus. Damping capacity of alloys is closely tied to the presence of defects including solute atoms, second phases and voids. The interaction between moving dislocations and point defects is one of the major internal damping mechanisms of magnesium alloys so the precipitates influence the damping capacity and contribute to damping properties.

Keywords: Vibration Amplitude, Deformation Amplitude, Magnesium Alloy, Internal Damping, Resonant Frequency

\section{Acknowledgement}

This work has been supported by Scientific Grant Agency of Ministry of Education of Slovak Republic and Slovak Academy of Sciences, No.1/0683/15.

\section{References}

[1] SEUNGH, B. (2000). High damping Fe - Mn martensitic alloys for engineering applications. In: Nuclear Engineering and Design, Vol. 198, No. 3, pp. 241-252. ISSN 0029-5493.

[2] AVEDESIAN, M. M., BAKER, H. (1999). Magnesium and Magnesium Alloys, pp. 314. Materials Park OH: ASM International. ISBN 0871706571.

[3] ZHANG, Z., ZENG, X., DING, W. (2005). The influence of heat treatment on damping response of AZ91D magnesium alloy. In: Materials Science and Engineering, Vol. 392, No. 1 - 2, pp. 150-155. ISSN 0921-5093.

[4] DRESSLEROVÁ, Z., PALČEK, P. (2014). Temperature dependence of the internal friction measured at different excitation voltages, pp. 287-290, Manufacturing Technology, vol. 14, No. 3, ISSN 1213-2489.

[5] SUGIMOTO, K., MATSUI, K., OKAMOTO, T., KISHITAKE, K. (1975). Effect of Crystal Orientation on Amplitude-Dependent Damping in Magnesium, pp. 647, Trans JIM 16

[6] RIEHEMANN, W. (1998). Internal Friction in Magnesium Material, pp. 61, In B. L. Mordike and K. U Kainer (Eds) Magnesium Alloys and Their Applications, Frankfurt: Werkstoff-Informationsgesellschaft.

[7] HURTALOVÁ, L., TILlOVÁ, E. (2013). Elimination of the negative effect of FE-rich intermetallic phases in secondary (recycled) aluminium cast alloy, pp.44-50. Manufacturing Technology, Vol.13, Num.1, ISSN 12132489.

[8] AVEDESIAN, M., M., BAKER, H. (1999). Magnesium and Magnesium Alloys, pp. 298, Materials Park OH: ASM International, ISBN 0-87170-657-1.

[9] WAN D., WANG J., LIN L., FENG Z., YANG, G. (2008). Damping properties of Mg-Cabinary alloys, pp. 2438 Physical B 403

[10] ZATKALÍKOVÁ, V., MARKOVIČOVÁ, L., BELAN, J., LIPTÁKOVÁ, T. (2014). Variability of local corrosion attack morphology of AISI 316Ti stainless steel in aggressive chloride environment, pp.493-497. Manufacturing Technology, Vol.14, Num.3, ISSN 1213-2489.

[11] PORUBČAN, J., PALČEK, P., BLAŽEK, D., TROJANOVÁ, Z. (2012). Internal friction in extruded aluminium alloy, pp.197-202. Solid State Phenomena: Internal friction and mechanical spectroscopy. Vol. 184, ISSN 10120394

[12] BELAN, J., HURTALOVÁ, L., VAŠKO, A., TILLOVÁ, E. (2014). Metallography evaluation of IN 718 after applied heat treatment, pp.262-267. Manufacturing Technology, Vol.14, Num.3, ISSN 1213-2489.

[13] KASENČÁK, M. (2010). Vnútorné tlmenie zliatin horčíka v závislosti od amplitúdy deformácie: Dizertačná práca, Žilina: Žilinská Univerzita v Žiline, 97 p.

[14] NAMAŠNÝ, A. (2008). Štúdium vlastností horčíkových zliatin meraním vnútorného tlmenia: Dizertačná práca, Žilina: Žilinská Univerzita v Žiline, 90 p. 